\title{
La Guía Digital del Patrimonio Cultural de Andalucía apuesta por la integración
}

\begin{abstract}
El IAPH ha publicado en su portal web la Guía Digital del Patrimonio Cultural de Andalucía, herramienta que facilita el conocimiento de los bienes patrimoniales andaluces. La guía se constituye como una fuente de referencia para obtener información sobre el patrimonio histórico de los municipios de Andalucia desde un enfoque integrador y cercano al territorio. La aplicación permite obtener de forma integrada el conjunto de información patrimonial disponible por cada uno de los municipios andaluces a partir de diferentes recursos de información: imágenes, cartografía, recursos electrónicos, bases de datos, etc. La dirección es www.iaph. es/web/canales/conoce-el-patrimonio/guia-digital
\end{abstract}

En la actualidad estamos asistiendo al surgimiento de una nueva realidad social y económica basada en la gestión y acceso al conocimiento. Este nuevo fenómeno está afectando de manera profunda a las organizaciones públicas por ser las principales generadoras de la información de uso público y porque tienen la obligación de adaptarse a los nuevos requisitos impuestos por la sociedad y la tecnología. La modernización del sector público pasa por un nuevo esquema de relaciones con la ciudadanía y las empresas, donde los objetivos deben ser la eficiencia y la contribución para generar riqueza.

En este sentido, el IAPH desarrolla desde su creación las funciones de integración, coordinación y sistematización de la información y documentación en materia de patrimonio histórico, con la finalidad de contribuir al estudio y conocimiento de los bienes culturales andaluces. Producto de este esfuerzo es la Guia Digital, que recopila por cada uno de los municipios andaluces un conjunto de información descriptiva, gráfica y cartográfica, de sus principales bienes muebles e inmuebles, rutas culturales, recursos electrónicos, bibliografía, información paisajística, etc.

Esta información generada por el IAPH cumple los criterios de calidad, fiabilidad y exhaustividad exigibles a los organismos públicos. La Guía Digital se presenta como una herramienta de transferencia del conocimiento generado por el IAPH que bajo criterios de transparencia y fiabilidad se constituye como un inventario de recursos patrimoniales, potencial generador de riqueza.

El IAPH, con la Guia Digital del Patrimonio Cultural, pretende promover la cohesión social a través de la participación y la colaboración con las diferentes administraciones, agentes y ciudadanía, en la mejora y puesta en valor de la información patrimonial. El conocimiento sobre el patrimonio cultural es activo para el desarrollo territorial y el bienestar social: El acceso a dicho conocimiento genera concienciación social en relación con sus valores. La difusión al conjunto de la ciudadanía a través del acceso a documentación especializada, bases de datos, rutas culturales, etc. promueve el interés por su conservación, facilita la investigación a otros agentes y potencia el turismo cultural.

Con la Guia Digital del Patrimonio Cultural el IAPH apuesta por ofrecer a la ciudadanía una visión integrada de la información patrimonial. La Guía Digital del Patrimonio Cultural de Andalucia ofrece de una forma organizada, clara e intuitiva, la información patrimonial disponible del municipio a través de la integración de todos los productos de información desarrollados por el IAPH: Localizador Cartográfico del Patrimonio, Banco de Imágenes del Patrimonio
¿Qué ofrece la Guía Digital del Patrimonio Cultural de Andalucía?

- Datos generales del municipio con webs de referencia

- Patrimonio inmueble (arquitectónico, arqueológico y etnológico): 24.000 registros sobre bienes inmuebles.

- Patrimonio mueble: 69.500 registros sobre bienes muebles desde la época romana hasta la actualidad.

- Bibliografía de patrimonio cultural: 40.000 referencias bibliográficas.

- Imágenes: 15.000 documentos gráficos,

imágenes multirresolución y videos inmersivos.

- Recursos electrónicos: 1.220 recursos

electrónicos.

- Paisaje cultural: 32 demarcaciones paisajísticas.

- Rutas culturales: 16 rutas culturales.

- Monografías multimedia: 6 monografías multimedia.

- Cartografía digital: 4.500 bienes georreferenciados.

Cultural, Base de Datos del Patrimonio Inmueble de Andalucia, Patrimonio Mueble de Andalucia, Bibliografía de Patrimonio Histórico y Rutas Culturales.

Con sus distintas aplicaciones web, el IAPH pretende acercar a la ciudadanía al patrimonio cultural de Andalucia a través de diferentes percepciones; desde el enfoque integrador y cercano al territorio que representa la Guia Digital del Patrimonio Cultural, hasta las búsquedas más temáticas y especializadas del resto de las aplicaciones web.

La orientación estratégica al usuario como máxima del IAPH establece como línea de trabajo fundamental llevar a cabo procesos de mejora continua tanto de la información como en el desarrollo de nuevas vias de interacción con la ciudadanía.

En cuanto a la información ofrecida la Guía Digital incluye a los denominados nuevos patrimonios o patrimonios emergentes, esto es, paisaje cultural, patrimonio del siglo XX y paisajes culturales.

Lorena Ortiz Lozano

Centro de Documentación y Estudios del IAPH 